\title{
Free-living Neoparamoeba perurans depth distribution is mostly uniform in salmon cages, but reshaped by stratification and potentially extreme fish crowding
}

\author{
Daniel W. Wright ${ }^{1,4, *}$, Barbara Nowak ${ }^{2}$, Frode Oppedal $^{3}$, Andrew Bridle ${ }^{2}$, \\ Tim Dempster ${ }^{1}$
}

\author{
${ }^{1}$ Sustainable Aquaculture Laboratory - Temperate and Tropical (SALTT), School of BioSciences, University of Melbourne, \\ Parkville, VIC 3010, Australia \\ ${ }^{2}$ Institute of Marine and Antarctic Studies, University of Tasmania, Launceston, TAS 7250, Australia \\ ${ }^{3}$ Institute of Marine Research, 5984 Matredal, Norway \\ ${ }^{4}$ Present address: Institute of Marine Research, 5984 Matredal, Norway
}

\begin{abstract}
Understanding the spatio-temporal positioning of hosts and their parasites in freeliving states is useful in devising methods to diminish parasite encounters in animal production systems. We explored the potential for depth-based control methods of the amoebic gill disease (AGD) agent, Neoparamoeba perurans, in salmon mariculture systems by conducting: (1) depthstratified $N$. perurans water sampling surveys in 2 years, and (2) a mensurative experiment comparing depth distributions of $N$. perurans and salmon hosts in commercial salmon sea-cages. From water sampling mostly at marine salinities, $N$. perurans abundance (quantitative PCR-derived cells $\mathrm{l}^{-1}$ ) varied among years, but overall, neither depth, time since freshwater bathing, temperature and salinity were predictors of $N$. perurans abundance. However, at 1 survey time, depth patterns in $N$. perurans abundance appeared during strong vertical salinity gradients following rainfall (at 1 site, salinity ranged between 14 and $35 \mathrm{~g} \mathrm{l}^{-1}$ ), with greater numbers of cells below a less saline surface layer. This suggested that salinity mediates $N$. perurans depth distribution during intermittent halocline development. Fish depth distribution monitoring revealed intense fish crowding, with local swimming densities up to 5 times stocking densities, typically at the surface at night. Simultaneously collected daytime water samples during low levels of fish crowding, with stock scattered amongst upper and lower cage sections, revealed no relationship between $N$. perurans and fish depth distributions. If intense fish crowding in narrow depth bands leads to high concentrations of $N$. perurans in cage environments and increased AGD risk, behavioural manipulations that vertically spread fish could be a successful AGD mitigation strategy.
\end{abstract}

KEY WORDS: Amoebic gill disease $\cdot$ Neoparamoeba perurans $\cdot$ Salmo salar $\cdot$ Depth $\cdot$ Swimming density · Aquaculture

\section{INTRODUCTION}

The marine amoeba Neoparamoeba perurans, which causes amoebic gill disease (AGD), is one of the major parasites of concern in salmon sea-cage

${ }^{*}$ Corresponding author: daniel.william.wright@imr.no culture, with outbreaks recorded in all major salmonproducing regions (Oldham et al. 2016). In the most extreme case, summer-autumn AGD outbreaks have persisted in the Atlantic salmon Salmo salar industry within Tasmania since its inception 3 decades ago

( ) The authors 2017. Open Access under Creative Commons by Attribution Licence. Use, distribution and reproduction are unrestricted. Authors and original publication must be credited. 
(Munday et al. 1990, 2001, Oldham et al. 2016). Despite the search for alternative controls and the start of programs to selectively breed salmon for AGD resistance (e.g. Kube et al. 2012), the same labour-intensive and partially-effective freshwater bathing treatments used to control AGD in the 1980s are still practiced today (Nowak 2012), with limited innovation of new control methods.

Many new preventive methods have surfaced for another important parasite, the salmon louse Lepeophtheirus salmonis (Dempster et al. 2009, Korsøen et al. 2012, Stien et al. 2012, 2016, Nilsen et al. 2017), after understanding the spatio-temporal depth distribution of its free-living infective larvae and salmon hosts in sea-cage environments (Heuch et al. 1995, Oppedal et al. 2011). Knowledge of how salmon hosts and free-living $N$. perurans distribute within seacages could therefore spur on the development of prophylactic techniques for $N$. perurans.

The depth-related swimming behaviour of salmon in sea-cages is well known in Norwegian coastal and fjord settings. Salmon adjust their vertical position by trading off between internal and external factors. Important environmental variables include light, temperature, salinity, dissolved oxygen, water currents and turbidity, while identified internal drivers consist of feeding or hunger status and the avoidance of perceived threats, such as predators (reviewed by Oppedal et al. 2011). In heterogeneous cage environments, salmon prefer to swim at specific depths, mostly driven by photo- and thermo-regulation (e.g. Oppedal et al. 2007). When fish feed and are hungry, they position themselves in the area that feed is dispensed, usually in surface waters (Oppedal et al. 2011). This information has been used to model and predict Atlantic salmon swimming depths and densities within cages in Norway (Føre et al. 2009, 2013). However, in SE Tasmania, Australia, caged Atlantic salmon swimming behaviour is yet to be examined, and differences may be expected due to disparate environmental conditions (e.g. strong tidal currents, warm, oxygen-deficient waters and higher light irradiance levels) and inner motivations of fish (e.g. seal presence, increased risk of oxygen and temperature stress and different feeding regimes).

By comparison, limited information exists on the spatio-temporal distribution of free-living $N$. perurans. In the last decade, $N$. perurans was confirmed as the disease-causing agent of AGD (Young et al. 2007, 2008, 2014, Crosbie et al. 2012), a molecular method for detecting it in the marine environment was developed (Bridle et al. 2010, 2015, Wright et al. 2015b), and the first assessments of its free-living distribution in salmon sea-cages were conducted (Bridle et al. 2010, Wright et al. 2015b, Hellebø et al. 2017). These assessments found that $N$. perurans occurs throughout the water column within farms holding AGD-affected stock in Australia (Bridle et al. 2010, Wright et al. 2015b) and in Norway (Hellebø et al. 2017). Further, free-living $N$. perurans are most abundant when clinical AGD levels are highest in stock and/or water temperatures are elevated (Wright et al. 2015b, Hellebø et al. 2017), and there have been occasions of higher abundance in the upper cage depths (Wright et al. 2015b, Hellebø et al. 2017). Surface concentrations of $N$. perurans have been hypothesised to result from either the swimming behaviour of caged salmon or the life history of this amoeba (Wright et al. 2015b). However, assessments have yet to compare depth-related free-living $N$. perurans concentrations with those of salmon in cages or take place during periods where strong vertical gradients in environmental variables exist that affect AGD risk, e.g. salinity and temperature (Clark \& Nowak 1999, Adams \& Nowak 2003, Oldham et al. 2016).

For parasites benefiting from host proximity for transmission, such as N. perurans (Nowak 2012), higher host density is theorised to increase the probability of a parasite encountering a new host. Positive relationships between host density and parasite intensity occur for this parasite type across a range of host taxa (Côté \& Poulin 1995, Arneberg et al. 1998). This also appears to be the case for $N$. perurans, with AGD progressing faster at higher stocking densities for salmon held in tanks (Crosbie et al. 2010), and some evidence of this in sea-cages (Douglas-Helders et al. 2004). Given that caged salmon can crowd in narrow depth bands at many times the densities at which they are stocked (reviewed by Oppedal et al. 2011), local swimming densities may contribute to free-living $N$. perurans abundance and encounter risk in sea-cage environments. If tight-packing in narrow depth intervals is an important driver of $N$. perurans abundance, avoiding these situations through salmon behaviour or cage environment manipulations may improve AGD management, e.g. vertical light movements (Wright et al. 2015a).

Here, we surveyed the distribution of free-living $N$. perurans in commercial salmon cages of SE Tasmania using depth-dispersed water sampling and quantitative PCR (qPCR) methods in the AGD outbreak season (summer-autumn) of 2015 to add to data from the 2014 season (Wright et al. 2015b). This enabled a $2 \mathrm{yr}$ data set to better decipher the relative importance of depth, as well as environmental and cage-specific variables in explaining $N$. perurans abundance in 
salmon sea-cages. In addition, we investigated the depth-related behaviour of caged salmon and examined its influence on the depth distribution of free-living $N$. perurans. This involved a mensurative experiment using echo-sounders to continuously monitor the vertical distribution of caged salmon populations in concert with depth-stratified water sampling to quantify $N$. perurans using qPCR techniques.

\section{MATERIALS AND METHODS}

\section{Neoparamoeba perurans depth survey}

In the $2015 N$. perurans depth survey, we surveyed $N$. perurans depth distribution in 9 commercial salmon cages (diameter $=38-54 \mathrm{~m}$, circumference $=$ $120-168 \mathrm{~m}$, cage depth $=10-19 \mathrm{~m}$ ) at 3 sites ( 3 cages site $^{-1}$ ) in the D'Entrecasteaux Channel, SE Tasmania, Australia (operated by TASSAL and Huon Aquaculture Company). Water samples were taken at depths of 0 (collected by slightly lifting the top of the Niskin bottle above the surface), 1, 2.5, 5 and $10 \mathrm{~m}$ in each cage at 4 times in 2015 on 20-22 January (time 1), 23-25 February (time 2), 18-26 March (time 3) and 29 April - 1 May (time 4) in 2015. We took single samples across the 5 depths, 9 cages and 4 times (for a total of 180 samples).

\section{Fish vs. $N$. perurans depth experiment}

In 2015 , a fish vs. $N$. perurans depth experiment was conducted at a separate salmon farm location from $N$. perurans depth surveys. We measured the depth distribution of salmon and free-living $N$. perurans in 3 square commercial cages (square $=30 \times 30 \mathrm{~m}$, cage depth $=10 \mathrm{~m}$ ) at the Northwest Bay lease (operated by TASSAL) in the northern end of the D'Entrecasteaux Channel, SE Tasmania, Australia. Fish depth was monitored for a $\sim 24 \mathrm{~h}$ period from 12:00 to 15:00 h $(\mathrm{GMT}+10)$, towards the end of which water sampling for $N$. perurans abundance occurred at 0 , $2.5,5,7.5$ and $10 \mathrm{~m}$ depth in daylight hours on 18-19 February (time 1), 24-25 March (time 2) and 5-6 May (time 3$)$. In total, 45 samples were taken (5 depths, 3 cages and 3 times).

\section{N. perurans water sampling and quantification}

For both the survey and experiment, water sampling for $N$. perurans was done as described by
Wright et al. (2015b). We positioned a 1.7 l Niskin bottle (General Oceanics) centrally at a quarter of the cage diameter within a cage above the transducer (fish and $N$. perurans depth experiment) or at the downstream end (survey of $N$. perurans depth). A rope system allowed the triggering of bottle closure at a range of depths by a cage-side operator (to avoid changes in normal fish behaviour). Collected water was poured from the sampler into $2 \times 11$ sterilised plastic bottles, transported on ice and refrigerated. All water samples were filtered within $24 \mathrm{~h}$ using filters $(1.2 \mu \mathrm{m}$ pore size, $47 \mathrm{~mm}$ diameter, GF/C Whatman glass microfibre, Sigma-Aldrich), a filter holder/receiver (Nalgene $^{\mathrm{TM}}$, Thermoscientific) and a Rocker 300 vacuum pump (JAVAC) operated at $30 \mathrm{kPa}$. Filters were inserted into $5 \mathrm{ml}$ vials with $1 \mathrm{ml}$ lysis buffer (4 M Urea, 1\% SDS, $0.2 \mathrm{M} \mathrm{NaCl}, 1 \mathrm{mM}$ sodium citrate) and frozen at $-20^{\circ} \mathrm{C}$. Real-time qPCR assays for $N$. perurans were then performed to calculate $N$. perurans cell abundance from thawed samples via a CFX Connect PCR Detection System (Bio-Rad). This distinguished a N. perurans-specific 18S rRNA gene sequence and estimated the number of cells based on the conversion: 2880 copies = 1 N. perurans cell (Wright et al. 2015b). N. perurans cell abundance was recalculated to cells $\mathrm{l}^{-1}$ for each sample to account for differences in sample volumes.

\section{Environmental and AGD-related variables}

At the time of water sampling at a cage in both the survey and experiment, salinity and temperature were recorded using a CTD profiler (model SD204, SAIV-AS) lowered through the water column from 0 to $10.25 \mathrm{~m}$. Recordings were then averaged at $0.5 \mathrm{~m}$ intervals. We also gathered information on days since the last freshwater bath, stocking density and AGD prevalence (percentage of 30-40 fish with macroscopic AGD spots or lesions). We reported on pre-bath AGD prevalence, which was measured before the most recent freshwater bath in a given cage (Wright et al. 2015b). Historical environmental data were obtained to help explain inter-annual patterns in $N$. perurans abundance. This consisted of daily sea surface temperature measurements at the mouth of the Huon Estuary (data provided by Huon Aquaculture Company, only available from March 2014) and daily rainfall recording at Dover (Australian Bureau of Meteorology weather station number 094020). 


\section{Fish depth monitoring}

In the fish vs. $N$. perurans depth experiment, salmon depth was measured and logged via an echo-integration system (model CageEye mk.II, Lindem Data Acquisition) connected to 3 transducers $\left(46^{\circ}\right.$ beam, $50 \mathrm{kHz}, 0.001 \mathrm{~s}$ pulse, $1 \mathrm{~s}$ echo listening, $3 \mathrm{~s}$ pulse interval) positioned $\sim 7 \mathrm{~m}$ underneath the bottom of each study cage (Bjordal et al. 1993). The transducers pointed up centrally at a quarter-distance spacing $(7.5 \mathrm{~m}$ of $30 \mathrm{~m}$ wide cages) from a cage edge running parallel to the tidal current direction. This was expected to capture a representative sample of the depth distribution for schooling fish inside large commercial cages, and capture fish depth patterns at the position of water sampling for $N$. perurans. Echo intensity (EI) recordings were condensed to average values every minute, and from $0.07 \mathrm{~m}$ depth increments between 0.25 and $10 \mathrm{~m}$ to average values every $0.5 \mathrm{~m}$. Across the 20 depth intervals (n), data were then converted to relative echo intensity (ER) using the formula

$$
\mathrm{ER}_{\mathrm{n}}=\mathrm{EI}_{\mathrm{n}}^{-\left(0.01 \times \sum \mathrm{EI}_{1-20}\right)}
$$

From this, observed fish densities (OFD or local swimming density, $\mathrm{kg} \mathrm{m}^{-3}$ ) at each depth interval were calculated by

$$
\mathrm{OFD}_{\mathrm{n}}=B \times \mathrm{ER}_{\mathrm{n}} \times V_{\mathrm{n}}^{-1}
$$

where $B$ is the total cage biomass, and $V$ is the cage volume within a $0.5 \mathrm{~m}$ band. Values were allocated to day or night categories according to local sunset and sunrise times of 20:15 and 6:36, 19:17 and 7:19, and $17: 09$ and 7:07 $\mathrm{h}$ for times 1,2 and 3 , respectively. Average minute data were used (see Figs. 3 \& 5); however, day and night OFD data were further condensed to average hourly values in preparation for statistical analyses of maximum OFD $\left(\mathrm{OFD}_{\max }\right.$ or local swimming density at the most preferred swimming depth), the depth of $\mathrm{OFD}_{\max }$ and the preference index (PI) or the quantified magnitude of preference for specific depths (Oppedal et al. 2007). For each hour, the PI was obtained from the equation

$$
\mathrm{PI}=\sum \mathrm{AER}_{\mathrm{n}} \div \sum D_{\mathrm{n}}
$$

for which $\sum A E R_{n}$ represents the sum of residual echo intensities above what was expected under a uniform fish distribution $(1 / 20$ depth intervals = 0.05 ) and $\sum D_{\mathrm{n}}$ is the count of those depths (Oppedal et al. 2007).

\section{Statistical analyses}

The importance of predictor variables in explaining $N$. perurans cell abundance within salmon cages at survey times in 2015 were examined using generalised additive mixed model (GAMM) analyses (Lin \& Zhang 1999) in R (R Core Development Team, version 3.1.0) via the mgcv package. GAMMs are nonparametric and use a smooth function to estimate predictor effects, in contrast to generalised linear mixed models (GLMMs) that fit a linear function and rely on normally distributed data. We opted for GAMMs in favour of GLMMs used in previous work (Wright et al. 2015b), because 2015 data were nonnormal even after data transformation as a result of low $N$. perurans cell abundance. Untransformed $N$. perurans cell abundance (cells $\mathrm{l}^{-1}$ ) was set as the response variable, and predictors used as fixed effects were depth, time since freshwater bathing, water temperature and salinity (Wright et al. 2015b). Site was included as a random factor. Model selection was determined from Akaike's information criterion (AIC) (Akaike 1973). The best model was one with the lowest AIC value, and a simpler model was considered better than one with an additional variable if the difference in AIC was $\leq 2$ (Burnham \& Andersen 2002). We also used Akaike weights $\left(W_{\mathrm{i}}\right)$ to evaluate the relative likelihood of each model, with higher weights indicating improved support (Burnham \& Andersen 2002). These analyses were repeated for a 2014 dataset pooled across 3 times in March, April and June from a previous survey study (Wright et al. 2015b), a 2015 dataset pooled across 4 times in January, February, March and April-May from this survey study and finally a multi-year survey dataset pooled across all 7 times. We also assessed inter-annual differences in $N$. perurans cell abundance between 2014 and 2015 surveys using a Mann-Whitney $U$-test.

For time 3 of the fish vs. N. perurans depth experiment (the only time $N$. perurans cells were detected), we examined differences in $\log _{10}(x+1)$-transformed OFD measurements at the depth of $N$. perurans water samples from all replicate cages between those that were positive and negative using $t$-tests. These were performed for the OFD recorded at the exact minute of sampling ( $0 \mathrm{~min})$, the previous $1 \mathrm{~min}$, or average OFD values from the previous 10, $60(1 \mathrm{~h}), 360(6 \mathrm{~h})$ or 1440 min (1 d) of sampling within a given cage. OFD at the sampling depth in a cage was calculated by averaging OFD recordings in the $1.25 \mathrm{~m}$ above and below the sampling depth $(0.25-1.25$ for $0 \mathrm{~m}, 1.25-3.75$ for $2.5 \mathrm{~m}, 3.75-6.25$ for $5 \mathrm{~m}, 6.25-8.75$ for $7.5 \mathrm{~m}$ and 
8.75-10.0 m for $10 \mathrm{~m}$ ). Mean hourly $\mathrm{OFD}_{\max }$ values with a $\log _{10}(x+1)$ transformation pooled from replicate cages were compared between time of day (day or night) and monitoring period (time 1-3) using a 2 -factor ANOVA. Significant results were followed by Tukey HSD post hoc comparisons to determine statistically different groups. Normality and equality of variance was checked using Shapiro-Wilk tests and residual plots, respectively, leading to data transformations where necessary. Significance was set at $\alpha=$ 0.05 , and error values refer to standard errors.

\section{RESULTS}

\section{Neoparamoeba perurans depth survey}

Preceding heavy rainfall caused a less saline (minimum of $14 \mathrm{~g} \mathrm{l}^{-1}$ ) and warmer surface layer (maximum of $20^{\circ} \mathrm{C}$ ) in study cages at time 1 . Less pronounced stratification was present at time 2 (minimum salinity of $29 \mathrm{~g} \mathrm{l}^{-1}$ ) and became mostly absent thereafter (Fig. 1). Mean abundance (in cells $\mathrm{l}^{-1}$ ) of $N$. perurans cells was low at times $1(0.04 \pm 0.02), 2(0.10 \pm 0.07)$, and $3(0.02 \pm 0.02)$, but increased at time $4(0.35 \pm$ 0.24 ; Fig. 1). The comparatively elevated $N$. perurans cell abundance at time 4 was matched by the highest bathing frequency (Table 1). Based on pre-bath gill scores, AGD was less prevalent at time 4, although these scores were potentially misleading because of changing bathing frequency and environmental conditions throughout the survey (Table 1, Fig. 1). Small progressive increases in stocking densities were seen in study cages over time (Table 1).

At time 1 when brackish water was present at the surface, GAMM analyses revealed that the model using depth best explained $N$. perurans cell abundance (Table S1, in the Supplement at www.int-res. com/articles/suppl/q009p269_supp.pdf). The model coefficient indicated that $N$. perurans cells were more abundant deeper in the water column $(\mathrm{df}=6.4$, $\mathrm{R}^{2}=0.10, \mathrm{p}=0.02$; see Table S1 in the Supplement. In contrast, at times 2-4 when vertical temperature and salinity gradients weakened or vanished, no models performed better than the null model in explaining $N$. perurans abundance (Tables S2-S4 in the Supplement).

\section{Inter-annual variation in $\boldsymbol{N}$. perurans depth}

N. perurans cells were more abundant in 2014

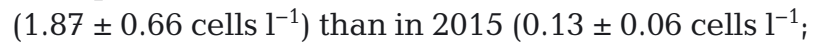

$W=16696, \mathrm{p}<0.0001$; Fig. 2). This was in conjunction with substantially less rainfall in $2014(271 \mathrm{~mm}$ from January-June) relative to 2015 (507 $\mathrm{mm}$ from January-June; Fig. 2). Depth patterns also varied between years, with greater numbers of $N$. perurans cells in surface waters at time 1 in 2014 (after minimal rainfall) and the opposite at time 1 in 2015 (after $116 \mathrm{~mm}$ of rainfall on 14-15 January 2015; Fig. 2). However, at all other times, no depth-related pattern existed. GAMM analysis revealed that temperature weakly explained $N$. perurans cell abundance in $2014\left(\mathrm{df}=6.8, \mathrm{R}^{2}=0.04, \mathrm{p}=0.01\right.$; Table S5 in the Supplement), with more cells at higher temperatures (Fig. 2). However, for 2015 and the multi-year dataset (2014 and 2015 combined), the addition of predictors did not help explain $N$. perurans cell abundance beyond null models (Tables S6 \& S7 in the Supplement).

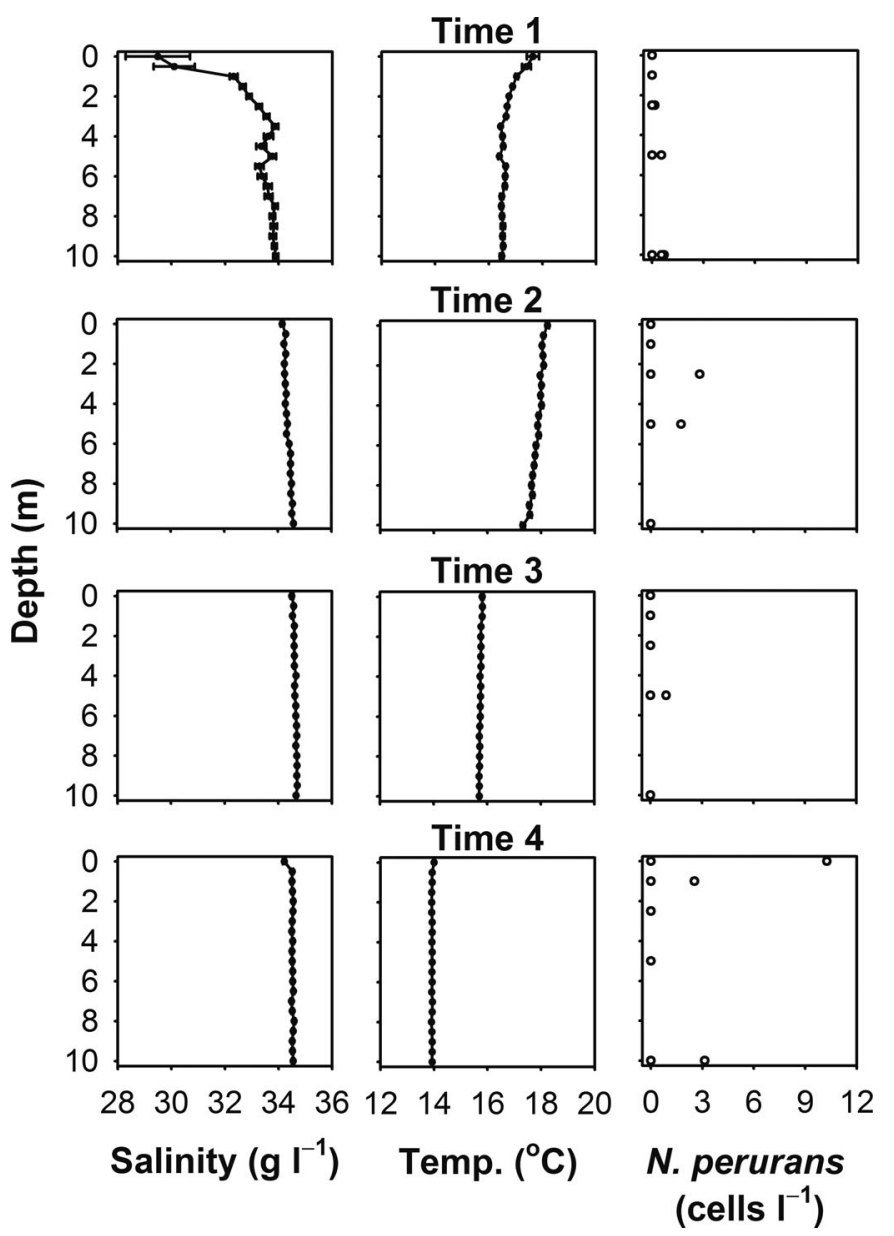

Fig. 1. Mean $( \pm \mathrm{SE})$ of temperature and salinity at $0.5 \mathrm{~m}$ depth increments (solid circles) and Neoparamoeba perurans cell abundance at $0,1,2.5,5$ and $10 \mathrm{~m}$ (open circles represent individual data points) in surveyed Atlantic salmon Salmo salar cages at times 1-4 in 2015 (1: 20-22 January; 2: 23-25 February; 3: 18-26 March; 4: 29 April-1 May) 
Table 1. Mean $( \pm \mathrm{SE}$ ) of pre-bath amoebic gill disease (AGD) level, time since freshwater bathing and stocking density of Atlantic salmon Salmo salar for surveyed salmon cages at times 1-4 (see Fig. 1 for exact times). Ranges are displayed in parentheses; all values are based on 9 cages at each time point

\begin{tabular}{|lllc|}
\hline Time & $\begin{array}{c}\text { Pre-bath AGD } \\
\text { prevalence (\%) }\end{array}$ & $\begin{array}{c}\text { Time since } \\
\text { bathing (d) }\end{array}$ & $\begin{array}{c}\text { Stocking density } \\
\left(\mathrm{kg} \mathrm{m}^{-3}\right)\end{array}$ \\
\hline 1 & $50.7 \pm 8.5(23-100)$ & $27.0 \pm 4.3(9-47)$ & $5.3 \pm 0.5(2.6-6.9)$ \\
2 & $54.1 \pm 6.8(15-100)$ & $28.8 \pm 4.4(6-48)$ & $5.6 \pm 0.5(3.1-7.6)$ \\
3 & $60.6 \pm 4.5(30-87)$ & $25.9 \pm 3.6(14-49)$ & $5.7 \pm 0.5(2.8-7.5)$ \\
4 & $38.9 \pm 2.6(20-72)$ & $17.8 \pm 3.2(7-35)$ & $6.6 \pm 0.6(3.8-8.3)$ \\
\hline
\end{tabular}

3 than in all other periods, values on Days 2 and 3 were higher than those on Day 1, and recordings on Day 2 were above those on Night 1 ( $p<0.05$; Table 2$)$. Similarly, mean preference indexes were elevated ( $>2$ ), indicating increased crowding at specific cage depths, during Nights 2 and 3 and on Day 2 (Table 2). The highest $\mathrm{OFD}_{\max }$ recorded using hourly average data was $52 \mathrm{~kg} \mathrm{~m}^{-3}$ or 5.2 times the mean stocking density on Night 3 (Table 2). Based on minute average data, maximum OFD values reached $116 \mathrm{~kg}$ $\mathrm{m}^{-3}$ or 14.2 times the mean stocking density on Night 2 (Fig. 4; Table 2).

$N$. perurans cells were undetected in depth-stratified water samples at times 1 or 2, and were only found in low abundance at time 3 (Fig. 4). Time 3 coincided with homogeneous salinity and temperature conditions throughout cage depths and low levels of fish crowding (Fig. 4). Comparisons of mean OFD measurements at the sampling depth between samples with and without $N$. perurans cells at time 3 were not statistically different (Fig. 5). This was the case for mean OFD recordings at 0 min of samples being taken when the largest separation occurred (present vs. absent: 11.5 and $9.8 \mathrm{~kg} \mathrm{~m}^{-3}, t=-1.6, \mathrm{p}=$ $0.1)$, and recordings in the $1,10,60,360(6 \mathrm{~h})$ or 1440 min $(1 \mathrm{~d})$ prior to sampling $(t=-0.05$ to $-1.1, \mathrm{p}>$ 0.3 ; Fig. 5). Of note, a $7.5 \mathrm{~m}$ water sample, corresponding to the highest mean OFD at sample depth at 0 $\min \left(25.3 \mathrm{~kg} \mathrm{~m}^{-3}\right.$ or 2.6 times the stocking density) and in the previous $10 \mathrm{~min}\left(15.8 \mathrm{~kg} \mathrm{~m}^{-3}\right.$ or 1.6 times the stocking density), contained the highest $N$. perurans cell abundance recorded ( 2.0 cells $\mathrm{l}^{-1}$ compared

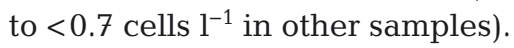

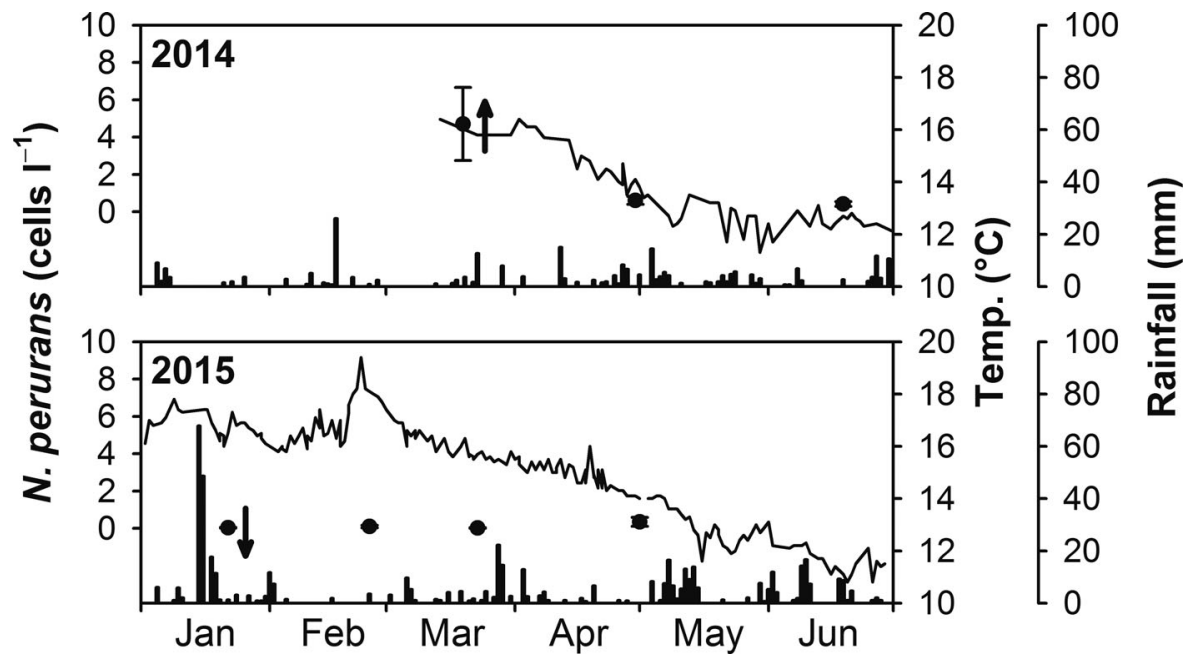

Fig. 2. Mean ( \pm SE) Neoparamoeba perurans cell abundance (filled circles) at each time in surveyed Atlantic salmon Salmo salar cages in the 2014 and 2015 surveys. When depth was the main explanatory factor in $N$. perurans cell abundance (determined by GLMM or GAMM analyses), the direction of depth effects is displayed (up arrow for more $N$. perurans cells in surface waters, and down arrow for greater numbers at lower cage depths). Daily rainfall (Dover station 094020, bars) and water temperature at $0 \mathrm{~m}$ (Roaring Beach lease provided by Huon Aquaculture Company, lines) are plotted from January-July in both years. No temperature data were available in January and February 2014 
Fig. 3. Observed fish density (OFD; colour coded) every minute between 0.25 and $10 \mathrm{~m}$ depth over $\sim 24 \mathrm{~h}$ periods in each of 3 Atlantic salmon Salmo salar cages at times 1-3 in 2015 (1: 18-19 February; 2: 24-25 March; 3: 5-6 May. The panel above each graph represents night- (black bars) and daytime (open bars) based on local sunrise and sunset times, and the boxes within the graphs indicate periods during which water sampling for Neoparamoeba perurans took place

\section{DISCUSSION}

Depth patterns in Neoparamoeba perurans abundance were mostly absent within salmon cages. In the 2014 season after low rainfall, surface concentrations of $N$. perurans were seen at 1 out of 3 survey times (Wright et al. 2015b). In the 2015 season after high rainfall, $N$. perurans were deeper in the water column during strong vertical gradients in salinity and temperature, but with uniform distribution at the remaining 3 survey times. GAMM analyses for surveys from each year and both years combined confirmed that
Time 1
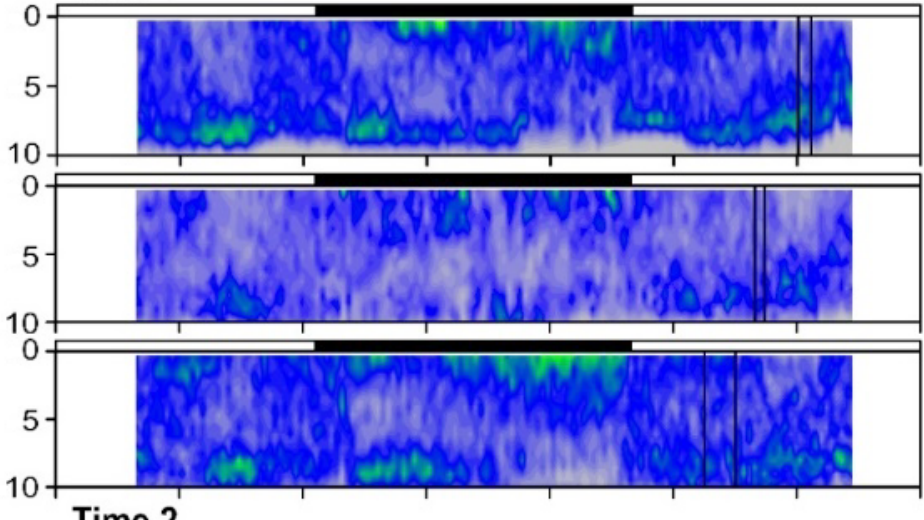

Time 2
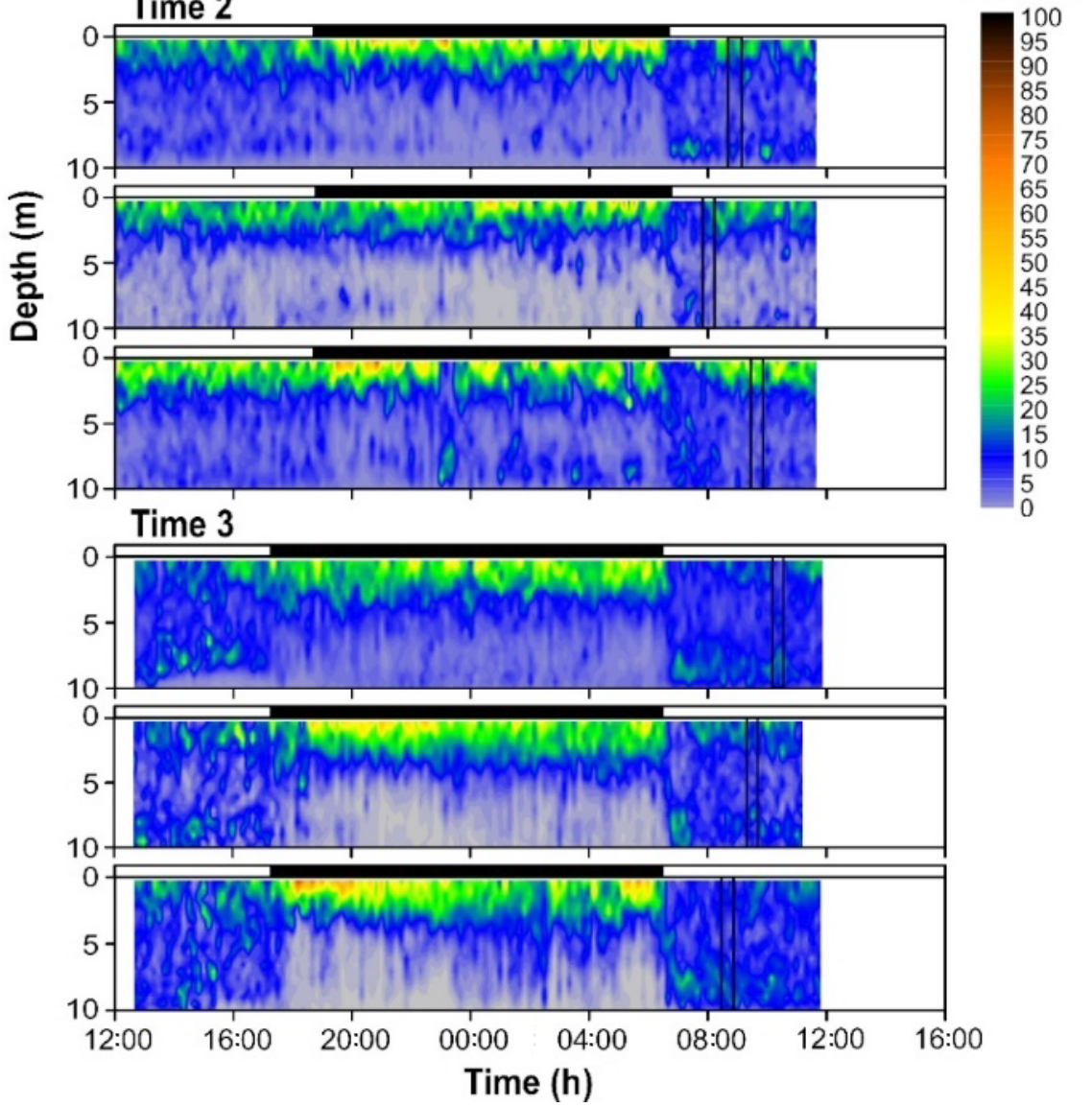

depth was not an important driver of amoebae abundance. Caged salmon usually displayed their typical diurnal behavioural pattern (Oppedal et al. 2011) of deep daytime and shallow nighttime swimming, although they also occupied surface waters throughout the day (possibly explained by hunger levels) and lower cage depths at night (if these were of preferred temperature). In this study, local swimming densities of caged salmon were unrelated to $N$. perurans presence; further work is needed to test if this remains the case when $N$. perurans abundance and salmon swimming densities are high. 

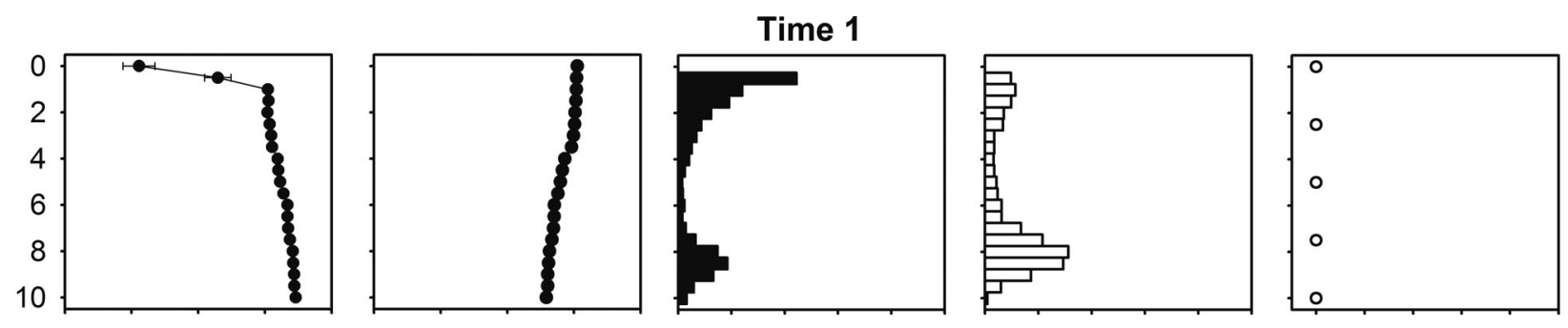

Time 2
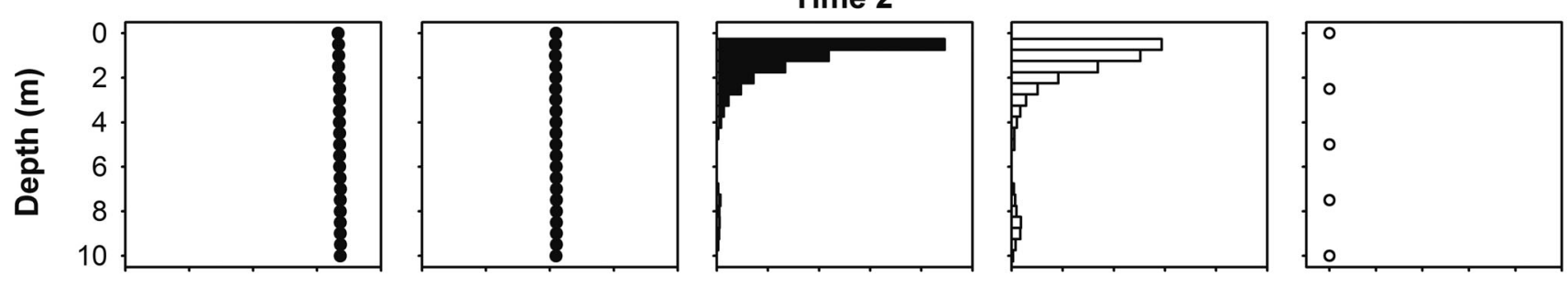

Time 3
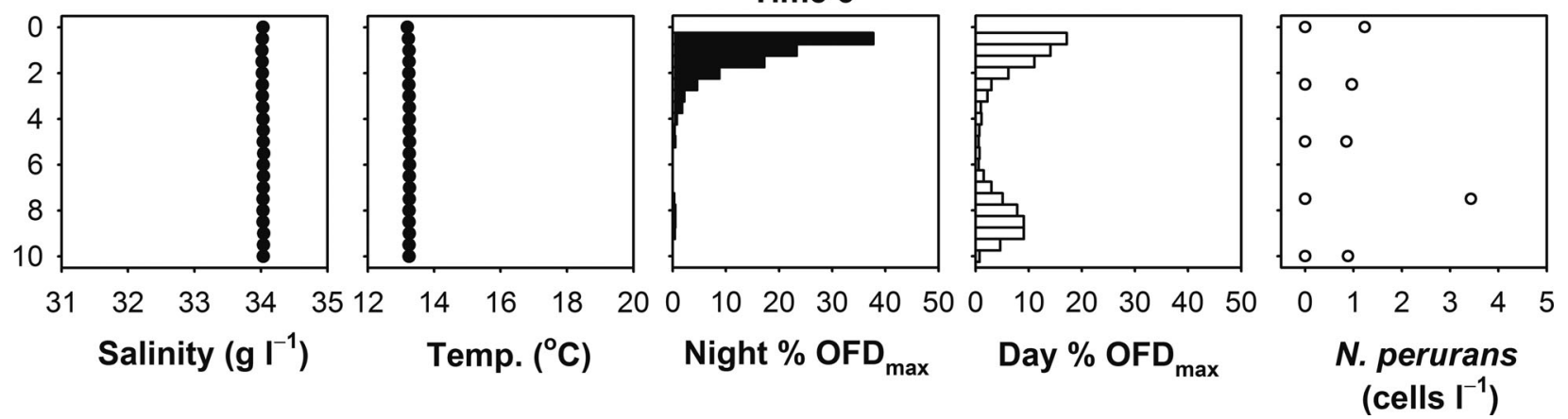

Fig. 4. Vertical patterns in environmental conditions (salinity and temperature as solid circles, mean $( \pm \mathrm{SE})$ at $0.5 \mathrm{~m}$ intervals), observed fish density (OFD; percentage of maximum OFD at each $0.5 \mathrm{~m}$ interval) during day- (open bars) and nighttime (solid bars), and Neoparamoeba perurans cell abundance (open circles) at times 1-3 in 2015 (see Fig. 3 for exact times)

Surveys in 2015 for $N$. perurans in salmon seacages did not detect high cell abundance in surface waters reported in 2014 at the same locations (Wright et al. 2015b). Furthermore, when data from 2014 and 2015 were scrutinised together, depth-related patterns of $N$. perurans in the water column were infrequent at specific survey times. In 2015, more cells were in deeper cage depths at 1 survey time, which was associated with brackish surface water conditions following heavy rainfall (down to $14 \mathrm{~g} \mathrm{l}^{-1}$ at $0 \mathrm{~m}$ ). This trend was also reported in an earlier assessment of the depth distribution of Paramoeba and Neoparamoeba spp. in AGD-affected salmon cages at a location with a halocline present and salinities of $28 \mathrm{~g} \mathrm{l}^{-1}$ at $0 \mathrm{~m}$ (Douglas-Helders et al. 2003). Freshwater runoff exiting the river mouth after rainfall may phys-

Table 2. Mean $( \pm \mathrm{SE})$ hourly maximum observed fish density $\left(\mathrm{OFD}_{\max }\right)$ values and preference indexes in triplicate Atlantic salmon Salmo salar cages during the day and at night for each of the 3 times (see Fig. 3 for exact times). Mean ( \pm SE) stocking densities at each time are

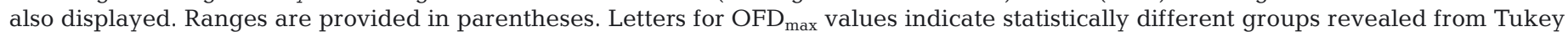

HSD comparisons following a 2-factor ANOVA using time and light conditions as factors, and OFD $\mathrm{max}_{\text {as }}$ the response variable

\begin{tabular}{|c|c|c|c|c|c|}
\hline Time & $\tau_{\text {Day }} \mathrm{OFD}_{\max }$ & $\left.\mathrm{kg} \mathrm{m}^{-3}\right) \overline{\text { Night }}$ & $\begin{array}{c}\text { Day } \\
-\end{array}$ & ce index - Night & $\begin{array}{l}\text { Stocking density } \\
\left(\mathrm{kg} \mathrm{m}^{-3}\right)\end{array}$ \\
\hline 1 & $13.0 \pm 0.4^{\mathrm{a}}(9.0-21.5)$ & $15.4 \pm 0.7^{\mathrm{ab}}(9.1-22.6)$ & $1.15 \pm 0.11(0.12-4.26)$ & $1.76 \pm 0.70(0.40-2.95)$ & $8.5 \pm 0.6(7.5-9.4)$ \\
\hline 2 & $19.6 \pm 1.1^{\mathrm{c}}(7.6-32.5)$ & $26.8 \pm 1.4^{\mathrm{d}}(10.2-47.3)$ & $4.41 \pm 0.23(0.76-7.48)$ & $6.18 \pm 0.31(0.75-9.97)$ & $8.3 \pm 0.5(7.5-9.1)$ \\
\hline 3 & $16.1 \pm 0.3^{\mathrm{bc}}(13.1-19.7)$ & $29.2 \pm 7.1^{\mathrm{d}}(18.9-52.0)$ & $1.48 \pm 0.06(0.76-2.01)$ & $4.91 \pm 0.25(2.10-10.42)$ & $10.2 \pm 0.2(9.9-10.5)$ \\
\hline
\end{tabular}




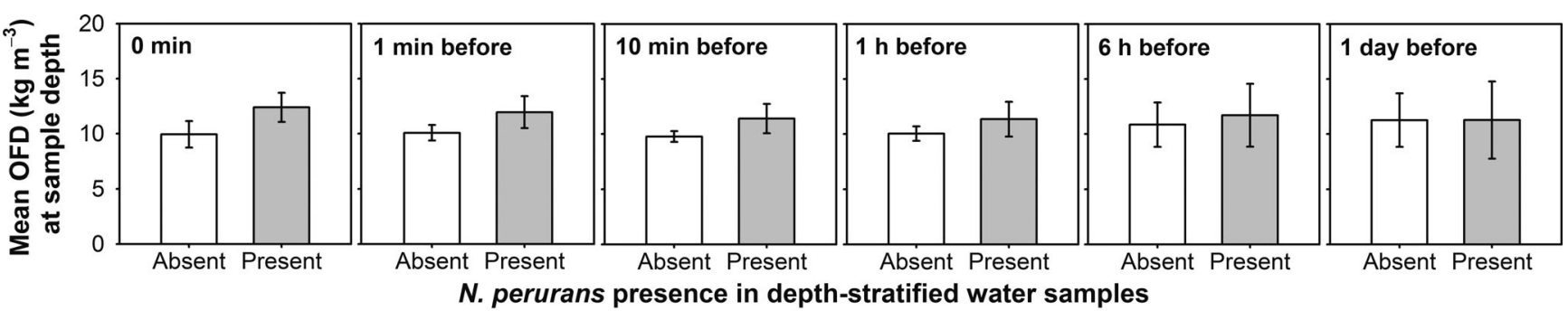

Fig. 5. Mean $( \pm \mathrm{SE})$ of observed fish density (OFD) values calculated at the minute of sampling or from the previous 1,10 , $60(1 \mathrm{~h}), 360(6 \mathrm{~h})$ or $1440 \mathrm{~min}(1 \mathrm{day}$, cells from left to right) within the $1.25 \mathrm{~m}$ above and below water samples where Neoparamoeba perurans was absent (open bar) or present (grey bar) at time 3 (5-6 May 2015)

ically push N. perurans out the surface brackish layer. Concomitantly, free-living N. perurans using contractile vacuoles to maintain inner cell osmolality equivalent to full-strength seawater (Lima et al. 2016) would become denser than surrounding water at lower salinities, potentially causing them to sink out of such layers. Buoyancy changes could allow marine amoebae to move away from unfavourable low-salinity surface conditions. Overall, strong vertical gradients in salinity were only temporary and it was most common that $N$. perurans distribution did not show distinct depth patterns (Wright et al. 2015b).

Fewer free-living $N$. perurans were observed in the months after a major rainfall event in 2015. That year, rainfall appeared to overrule the influence of temperature on N. perurans abundance detected in 2014 (Wright et al. 2015b). AGD outbreak magnitude is reduced or avoided under brackish surface water conditions (Clark \& Nowak 1999, Adams \& Nowak 2003, Oldham et al. 2016). This likely eventuates for 2 reasons. First, as discussed above, increased river discharge may flush $N$. perurans out of estuaries particularly at upper cage depths, reducing free-living $N$. perurans abundance and new AGD infections. Second, gill-attached N. perurans could dislodge or be adversely affected when hosts briefly or persistently reside in brackish surface water following rainfall. Increased shedding of mucus from the gills of salmon occurs during prolonged reductions in salinity (Roberts \& Powell 2003, 2005), and may be an important mechanism in $N$. perurans detachment. $N$. perurans attached to plastic substrates subjected to low salinities $\left(28 \mathrm{~g} \mathrm{l}^{-1}\right)$ either remain there using contractile vacuoles for osmotic regulation (Lima et al. 2016), or detach and assume floating rounded forms that are not expected to reproduce (Martin 1985, Cowie \& Hannah 2006). Extended low-salinity exposures will eventually cause lysis of $N$. perurans (Powell \& Clark 2003). Salinity reductions appear to diminish the abundance of free-living N. perurans in cage environments and control AGD outbreaks.
In SE Tasmania, the depth-related behaviour of caged salmon generally resembled that found in previous assessments in Norway (reviewed by Oppedal et al. 2011). Fish tended to occupy shallow depths at night and moved deeper during the day, which is diel behaviour widely reported in caged salmon (see Oppedal et al. 2011). However, during periods of thermal stratification, fish chose to swim at depths closest to their preferred optimal temperature range of $16-18^{\circ} \mathrm{C}$ (Johansson et al. 2006, 2009) for thermoregulation and intrinsic physiological performance benefits, regardless of light conditions (Oppedal et al. 2007, Stien et al. 2014). At one time, fish resided only near the surface throughout the day and night. This was unlikely motivated by thermal conditions, because vertical temperature differences were much less than those shown to drive depth selection of $0.2^{\circ} \mathrm{C}$ (Oppedal et al. 2007), and, at $16.2^{\circ} \mathrm{C}$, these temperatures fell within the optimal range for Atlantic salmon. Instead, fish may have been underfed and hungry, occupying upper cage depths in anticipation of surface-delivered feed (Oppedal et al. 2011). Reduced feeding by farmers during high water temperatures and low oxygen levels, to minimise fish metabolic rates and oxygen consumption (Forsberg 1997), might have occurred prior to fish depth monitoring and explained surface-dwelling fish. Excluding this observation of daytime crowding at the surface, the tightest packing of caged salmon was at night, also in shallow waters.

Observed fish density effects on free-living $N$. perurans presence were not detected in our mensurative experiment in commercial salmon sea-cages. However, very few $N$. perurans were detected, suggesting they were shed from gills infrequently and few were present in the water column. Further, at the only time salmon swimming densities and $N$. perurans abundance could be compared, salmon were evenly partitioned between the upper and lower cage subgroups and were not crowding in any depth band. Consequently, our findings cannot be easily extrapolated to 
conditions at the height of AGD outbreaks during intense fish crowding and high $N$. perurans abundance in the water column. The depth distribution of fish and free-living $N$. perurans in SE Tasmania indicate that a link is possible at those times. In homogeneous cage environments of $\sim 16.3^{\circ} \mathrm{C}$ in 2014 , free-living $N$. perurans were abundant in surface waters (Wright et al. 2015b). Analogously, during $16.2^{\circ} \mathrm{C}$ throughout depths in 2015, fish positioned in the upper cage depths during the most intense day-time crowding (mean packing index of 4.4, compared to $<1.5$ at other times). Hence, fish may have swum at the surface and driven the high $N$. perurans numbers there under identical conditions in the previous year. Future investigations examining the connection between fish and $N$. perurans depth distributions in cage environments should focus on the peaks of AGD outbreak (during low rainfall and high water temperatures) and extremes in fish crowding (mostly during night hours at the surface in this study).

\section{CONCLUSIONS}

From a multi-year dataset, we revealed that freeliving Neoparamoeba perurans are mostly ubiquitous throughout depths in salmon sea-cages and more abundant at high water temperatures when preceded by low rainfall. This implies that AGD cannot be avoided by excluding salmon from specific cage depth bands using behavioural and environmental manipulations, as is the case for Lepeophtheirus salmonis salmon lice (Dempster et al. 2009, Korsøen et al. 2012, Stien et al. 2012, 2016, Nilsen et al. 2017). However, our results do not preclude the possibility that behavioural and environmental approaches could be applied to reduce extreme local fish swimming densities, which were most common at night. Strategic deployment of depth-dispersed static and vertically moving artificial night lighting arrangements, that evenly spreads fish throughout cage depths, could slow AGD progression during outbreaks and improve salmon welfare more broadly (Juell et al. 2003, Oppedal et al. 2011, Wright et al. 2015a). While lights placed at single, static depths are in standard use to control maturation and the modifications we suggest to light placement, not intensity, are unlikely to alter stress levels in caged salmon, the repercussions of any modification to cage environments or salmon behaviour require careful assessment. Our study highlights the importance of understanding how hosts and parasites distribute spatio-temporally in farm environments to discover new parasite management tools.
Acknowledgements. We thank TASSAL and the Huon Aquaculture Company for providing extensive farm access and assistance. Thanks to Francisca Samsing, Fletcher Warren-Myers, Tina Oldham, Jessica Johnson-Mackinnon, Michael Sievers, Cassandra Pert and Kristoffer Rist Skøien for field assistance. Luke Barrett and Tim Jessop helped with statistical analyses. Funding was provided by an ARC Future Fellowship grant awarded to T.D.

\section{LITERATURE CITED}

Adams MB, Nowak BF (2003) Amoebic gill disease: sequential pathology in cultured Atlantic salmon, Salmo salar L. J Fish Dis 26:601-614

Akaike H (1973) Information theory and an extension of the maximum likelihood principle. In: Petrov BN, Caski F (eds) Proc Second International Symposium on Information Theory. Akademiai Kiado, Budapest, p 267-281

Arneberg P, Skorping A, Grenfell B, Read AF (1998) Host densities as determinants of abundance in parasite communities. Proc R Soc Lond B Biol Sci 265:1283-1289

Bjordal A, Juell JE, Lindem T, Ferno O (1993) Hydroacoustic monitoring and feeding control in cage rearing of Atlantic salmon (Salmo salar L.). In: Reinertsen H, Dahle LA, Jørgensen L, Tvinnereim K (eds) Fish farming technology. Balkema, Trondheim, p 203-208

Bridle AR, Crosbie PBB, Cadoret K, Nowak BF (2010) Rapid detection and quantification of Neoparamoeba perurans in the marine environment. Aquaculture 309:56-61

Bridle AR, Davenport DL, Crosbie PBB, Polinski M, Nowak BF (2015) Neoparamoeba perurans loses virulence during clonal culture. Int J Parasitol 45:575-578

Burnham KP, Andersen DR (2002) Model selection and multimodel inference: a practical information-theoretic approach, 2nd edn Springer, New York, NY

Clark A, Nowak BF (1999) Field investigations of amoebic gill disease in Atlantic salmon, Salmo salar L., in Tasmania. J Fish Dis 22:433-443

* Côté IM, Poulin R (1995) Parasitism and group size in social animals: a meta-analysis. Behav Ecol 6:159-165

* Cowie PR, Hannah F (2006) Responses of four isolates of marine naked amoebae to reductions in salinity. J Exp Mar Biol Ecol 337:196-204

Crosbie PBB, Bridle AR, Leef MJ, Nowak BF (2010) Effects of different batches of Neoparamoeba perurans and fish stocking densities on the severity of amoebic gill disease in experimental infection of Atlantic salmon, Salmo salar L. Aquacult Res 41:505-516

* Crosbie PBB, Bridle AR, Cadoret K, Nowak BF (2012) In vitro cultured Neoparamoeba perurans causes amoebic gill disease in Atlantic salmon and fulfils Koch's postulates. Int J Parasitol 42:511-515

*Dempster T, Korsøen Ø, Folkedal O, Juell JE, Oppedal F (2009) Submergence of Atlantic salmon (Salmo salar L.) in commercial scale sea-cages: a potential short-term solution to poor surface conditions. Aquaculture 288:254-263

* Douglas-Helders GM, O'Brien DP, McCorkell BE, Zilberg D, Gross A, Carson J, Nowak BF (2003) Temporal and spatial distribution of paramoebae in the water columna pilot study. J Fish Dis 26:231-240

* Douglas-Helders GM, Weir IJ, O'Brien DP, Carson J, Nowak BF (2004) Effects of husbandry on prevalence of amoebic gill disease and performance of reared Atlantic salmon (Salmo salar L.). Aquaculture 241:21-30 
Føre M, Dempster T, Alfredsen JA, Johansen V, Johansson D (2009) Modelling of Atlantic salmon (Salmo salar L.) behaviour in sea-cages: a Lagrangian approach. Aquaculture 288:196-204

Føre M, Dempster T, Alfredsen JA, Oppedal F (2013) Modelling of Atlantic salmon (Salmo salar L.) behaviour in sea-cages: using artificial light to control swimming depth. Aquaculture 388-391:137-146

Forsberg OI (1997) The impact of varying feeding regimes on oxygen consumption and excretion of carbon dioxide and nitrogen in post-smolt Atlantic salmon Salmo salar L. Aquacult Res 28:29-41

Hellebø A, Stene A, Aspehaug V (2017) PCR survey for Paramoeba perurans in fauna, environmental samples and fish associated with marine farming sites for Atlantic salmon (Salmo salar L.). J Fish Dis 40:661-670

*Heuch PA, Parsons A, Boxaspen K (1995) Diel vertical migration: a possible host-finding mechanism in salmon louse (Lepeophtheirus salmonis) copepodids? Can J Fish Aquat Sci 52:681-689

Johansson D, Ruohonen K, Kiessling A, Oppedal F, Stiansen JE, Kelly M, Juell JE (2006) Effect of environmental factors on swimming depth preferences of Atlantic salmon (Salmo salar L.) and temporal and spatial variations in oxygen levels in sea cages at a fjord site. Aquaculture 254:594-605

Johansson D, Ruohonen K, Juell JE, Oppedal F (2009) Swimming depth and thermal history of individual Atlantic salmon (Salmo salar L.) in production cages under different ambient temperature conditions. Aquaculture 290: 296-303

Juell JE, Oppedal F, Boxaspen K, Taranger GL (2003) Submerged light increases swimming depth and reduces fish density of Atlantic salmon Salmo salar L. in production cages. Aquacult Res 34:469-478

Korsøen ØJ, Fosseidengen JE, Kristiansen TS, Oppedal F, Bui S, Dempster T (2012) Atlantic salmon (Salmo salar L.) in a submerged sea-cage adapt rapidly to re-fill their swim bladders in an underwater air filled dome. Aquacult Eng 51:1-6

Kube PD, Taylor RS, Elliott NG (2012) Genetic variation in parasite resistance of Atlantic salmon to amoebic gill disease over multiple infections. Aquaculture 364-365:165-172

*ima PC, Taylor RS, Cook M (2016) Involvement of contractile vacuoles in the osmoregulation process of the marine parasitic amoeba Neoparamoeba perurans. J Fish Dis 39: 629-633

Lin X, Zhang D (1999) Inference in generalized additive mixed models by using smoothing splines. J R Stat Soc Ser B Stat Methodol 61:381-400

Martin RE (1985) Population growth in stationary and suspension culture of Paramoeba pemaquidensis Page (Amoebida, Paramoebidae). J Protozool 32:738-739

Munday BL, Foster CK, Roubal FR, Lester RJG (1990) Paramoebic gill infection and associated pathology of Atlantic salmon, Salmo salar and rainbow trout, Salmo gairdneri in Tasmania. In: Perkins FO, Cheng TC (eds) Pathology in marine science. Academic Press, San Diego, CA, p 215-222

Munday BL, Zilberg D, Findlay V (2001) Gill disease of marine fish caused by infection with Neoparamoeba pemaquidensis. J Fish Dis 24:497-507

Editorial responsibility: Chris Noble,

Tromsø, Norway
Nilsen A, Nielsen KV, Biering E, Bergheim A (2017) Effective protection against sea lice during the production of Atlantic salmon in floating enclosures. Aquaculture 466: 41-50

Nowak BF (2012) Neoparamoeba perurans. In: Woo PTK, Buchmann K (eds) Fish parasites: pathobiology and protection. CAB International, Wallingford, p 1-18

Oldham T, Rodger H, Nowak BF (2016) Incidence and distribution of amoebic gill disease (AGD) - an epidemiological review. Aquaculture 457:35-42

Oppedal F, Juell JE, Johansson D (2007) Thermo- and photoregulatory swimming behaviour of caged Atlantic salmon: implications for photoperiod management and fish welfare. Aquaculture 265:70-81

\% Oppedal F, Dempster T, Stien LH (2011) Environmental drivers of Atlantic salmon behaviour in sea-cages: a review. Aquaculture 311:1-18

Powell MD, Clark GA (2003) In vitro survival and the effect of water chemistry and oxidative chemical treatments on isolated gill amoebae from AGD-affected Atlantic salmon. Aquaculture 220:135-144

Koberts SD, Powell MD (2003) Comparative ionic flux and gill mucous cell histochemistry: effects of salinity and disease status in Atlantic salmon (Salmo salar L.). Comp Biochem Physiol A Mol Integr Physiol 134:525-537

Roberts SD, Powell MD (2005) The viscosity and glycoprotein biochemistry of salmonid mucus varies with species, salinity and the presence of amoebic gill disease. J Comp Physiol B 175:1-11

* Stien LH, Nilsson J, Hevrøy EM, Oppedal F, Kristiansen TS, Lien AM, Folkedal O (2012) Skirt around a salmon sea cage to reduce infestation of salmon lice resulted in low oxygen levels. Aquacult Eng 51:21-25

* Stien LH, Fosseidengen JE, Malm ME, Sveier H, Torgersen T, Wright DW, Oppedal F (2014) Low intensity light of different colours modifies Atlantic salmon depth use. Aquacult Eng 62:42-48

Stien LH, Dempster T, Bui S, Glaropoulos A, Fosseidengen JE, Wright DW, Oppedal F (2016) 'Snorkel' sea lice barrier technology reduces sea lice loads on harvest-sized Atlantic salmon with minimal welfare impacts. Aquaculture 458:29-37

Wright DW, Glaropoulos A, Solstorm D, Stien LH, Oppedal F (2015a) Atlantic salmon Salmo salar instantaneously follow vertical light movements in sea cages. Aquacult Environ Interact 7:61-65

*Wright DW, Nowak B, Oppedal F, Bridle A, Dempster T (2015b) Depth distribution of the amoebic gill disease agent, Neoparamoeba perurans, in salmon sea-cages. Aquacult Environ Interact 7:67-74

Y Young ND, Crosbie PBB, Adams MB, Nowak BF, Morrison RN (2007) Neoparamoeba perurans n. sp., an agent of amoebic gill disease of Atlantic salmon (Salmo salar). Int J Parasitol 37:1469-1481

* Young ND, Dyková I, Snekvik K, Nowak BF, Morrison RN (2008) Neoparamoeba perurans is a cosmopolitan aetiological agent of amoebic gill disease. Dis Aquat Org 78: 217-223

* Young ND, Dyková I, Crosbie PBB, Wolf M, Morrison RN, Bridle AR, Nowak BF (2014) Support for the coevolution of Neoparamoeba and their endosymbionts, Perkinsela amoebae-like organisms. Eur J Protistol 50:509-523

Submitted: February 27, 2017; Accepted: June 16, 2017 Proofs received from author(s): July 27, 2017 